\title{
Evolution of a mind
}

\section{Eugenie C. Scott revels in the first volume of Richard Dawkins's frank new memoir.}

$\mathrm{R}$ ichard Dawkins is one of the world's best-known scientists - largely because of his tireless promotion of evolution and, more recently, atheism, through a succession of best-sellers, videos and public appearances. In An Appetite for Wonder, the first part of a two-volume memoir, Dawkins presents his life up to the publication of The Selfish Gene (Oxford University Press, 1976), the popularscience blockbuster that kick-started his career as a spokesperson for evolutionary biology.

As befits someone whose life's work has focused on the cumulative changes through time that we call evolution, Dawkins wants to share the forces and factors in his life that have shaped the person he has become. A bookish child, he neglected many opportunities provided by his nature-loving parents to explore and be inspired by the natural world. Given that he was born in Nairobi and spent his early years in what is now Malawi, it seems curious that the natural abundance around him did not kindle that spark. He does speak of developing a fondness for animals, but more through reading children's books such as Hugh Lofting's Doctor Dolittle series, noting, "I learned late to love watching wild creatures, and I have never been such an outdoor person as either my father or my grandfather."

The African interlude came about because Dawkins's father, Clinton John Dawkins, followed family tradition by working in the British foreign service. Dawkins presents his father, who was a forester, as independent, resourceful, inventive and willing to take big risks. When a distant relative unexpectedly bequeathed to John Dawkins the country estate Over Norton Park in Oxfordshire, UK, he moved the family back to England, renounced his government pension and turned the land into a working farm. Richard, then eight, was soon packed off to boarding school.

The picture Dawkins paints of his schools is, if not quite Dickensian, pretty awful: little boys lining up naked for cold morning baths, shivering in unheated rooms, choking down

DNATURE.COM For a celebration of The Selfish Gene, see: go.nature.com/383s7y confesses, an indifferent student, but a few teachers managed to stimulate an interest in science. It is clear that he did not come into his own intellectually until he was admitted - by the skin of his teeth - into the University of Oxford. There, at Balliol College, Dawkins was lucky enough to be tutored by the great ethologist Nikolaas 'Niko' Tin-

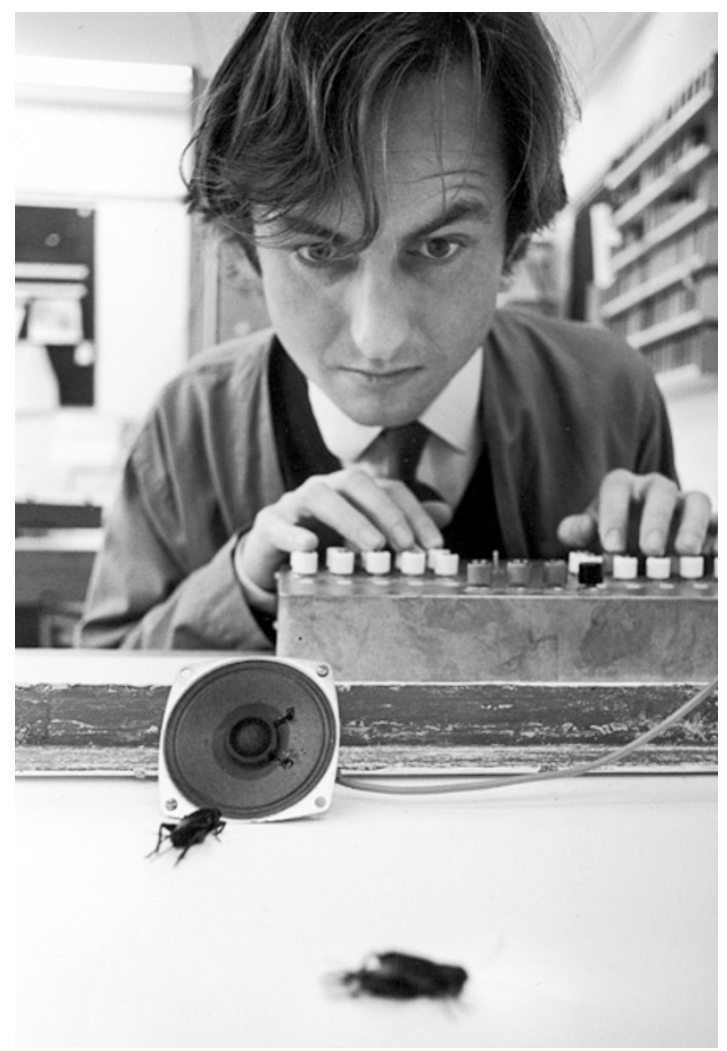

Richard Dawkins studying mating calls in crickets in 1976.

bergen, and became fascinated by animal behaviour.

The latter part of the book traces Dawkins's intellectual path from Oxford to his assistant professorship in zoology at the University of California, Berkeley (where he was swept up in the movement against the Vietnam War), and his return to Oxford as a young scientist. It describes his transition from a quantitatively oriented computer-programming experimentalist who modelled chick behaviour to the more theoretically oriented scientist we know today. I doubt if more than 1 in 10,000 readers of The Selfish Gene ever read his earlier experimental work. (I hadn't, either.) Inspired by the 1970s ferment over group and individual selection, kin selection and the like, that

\author{
book put the young \\ Dawkins on that \\ short list of scientists \\ who are able to make \\ complicated scientific
An Appetite for Wonder: The Making of a Scientist RICHARD DAWKINS Bantam: 2013. ideas understandable and exciting without oversimplifying them.

Dawkins is a polarizing figure, both widely praised and widely criticized. Supporters as well as detractors may be surprised at the honest depiction of an individual who comes across as both less saintly and less diabolical than media caricatures may have led them to expect. He loves poetry, and readily confesses to choking up when reading sentimental verse such as Hilaire Belloc's 1910 To the Balliol Men Still in Africa. He reflects with chagrin on his lack of concern about the rampant bullying that took place at his schools, and his support of what he now considers the bullying of some Berkeley faculty members by radical professors and students during the Vietnam War protests. Of the Berkeley experience, he notes, "I was still young, but not all that young. Should have known better." He readily confesses that scientific habits were slow in coming. It is a very honest book.

Charles Darwin wrote his autobiography for his family; for whom is Dawkins's written? I found the enumeration of ancestors in early chapters a bit of a slog. The middle chapters describing his childhood in Africa and school days in England should be of interest to all. The latter chapters, dealing with his mathematical modelling of evolution, might appeal more to scientists. Dawkins's atheist fans are not all necessarily in that camp, and might find the graphs and diagrams of behaviour patterns daunting.

However, throughout and as usual, Dawkins's writing is graceful, sparkling with anecdotes and wit. Those of us who struggle in our writing will be comforted to read the words: "Pretty much every sentence I write is revised, fiddled with, re-ordered, crossed out and re-worked." In other words, the elegant, functional design of his writing is accomplished through variation and selection. Why am I not surprised? -

Eugenie Scott is executive director of the National Center for Science Education in Oakland, California.

e-mail:scott@ncse.com 